\section{Mest for psykologer}

Monica Martinussen, red. Kvantitativ forskningsmetodologi i samfunns- og helsefag

343 s, tab, ill. Bergen: Fagbokforlaget, 2010. Pris NOK 429

ISBN 978-82-450-0888-3

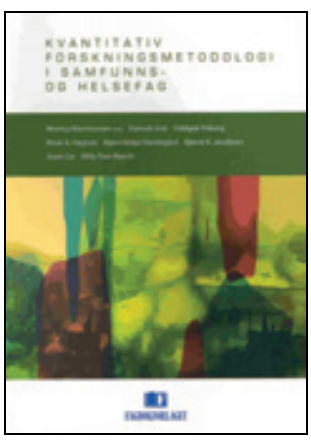

Målgruppen er ifølge omslaget doktorgradsstudenter og masterstudenter, men boken kan også være nyttig for forskere i samfunnsvitenskap og helsefag. Redaktøren skriver i forordet at hensikten er å presentere korte oversikter på norsk over sentrale temaer innenfor kvantitativ metodologi for stipendiater og forskere.

Forfatterne tar for seg et utvalg av til dels avanserte metoder, og nivået er trolig uegnet for de fleste masterstudenter. De ni kapitlene omfatter utvikling av måleinstrumenter, moderne testteori, G-teori, måling $i$ et krysskulturelt perspektiv, regresjonsanalyse, evaluering av tiltak, epidemiologi, metaanalyse og strukturelle likningsmodeller. Dette synes å være temavalg som spriker i litt forskjellige retninger, og jeg opplever heller ikke boken uten videre som en naturlig enhet, snarere som et knippe forskjellige oversiktsartikler der nøkkelordet er «kvantitativ». Redaktøren innrømmer da også at utvalget av metoder til dels er basert på personlige preferanser.

Tittelen kunne kanskje forlede en til å tro at dette kunne være en statistikkbok rettet mot medisinere med noe forskningserfaring. Det er det ikke. For en fagperson med bakgrunn i medisinsk forskningsmetode viste det seg å være uventet sterk vektlegging av psykometri og spørreskjemaer. Kanskje burde jeg ha forstått det uten å kikke på innholdsfortegnelsen. Ordet kvantitativ brukes atskillig sjeldnere i den medisinske og naturvitenskapelige tradisjonen enn i den samfunnsvitenskapelige. Det betyr selvsagt ikke at boken ikke kan være nyttig for andre enn psykologer, men en del av metodene som behandles, er temmelig avanserte, og man får neppe utbytte av et gitt kapittel uten å ha gode basiskunnskaper på forhånd.

Noen av kapitlene er likevel klart relevante for medisinere med interesse for forskningsmetoder. Det første kapitlet omhandler klassisk testteori og utvikling av spørreinstrumenter og har dermed klar relevans for forskere som utvikler og validerer spørreskjemaer, f.eks. om livskvalitet, og burde også være av interesse for dem som bruker ferdig validerte og allment aksepterte skjemaer i egne forskningsprosjekter.
Vanlig brukte, men ikke alltid forståtte, begreper og betegnelser som reliabilitet, faktoranalyse og Cronbachs alfa blir greit gjennomgått. Den moderne testteorien (Rasch-modeller etc.) forutsetter mer bakgrunnskunnskap enn det undertegnede besitter, for at man skal få fullt utbytte av lesningen. I epidemiologikapitlet gir forfatterne en god og lett tilgjengelig innføring i metoder og typiske problemer knyttet til å trekke konklusjoner fra epidemiologiske undersøkelser. Kapitlet om regresjonsanalyse er praktisk rettet, pedagogisk oppbygd og usedvanlig velskrevet. Det er nesten en minilærebok på norsk og helt sikkert veldig nyttig for mange medisinske stipendiater som strever med store datasett, modellering og anvendelse av statistisk metode utover det helt elementære.

Ville jeg anbefale boken for en doktorgradsstudent med medisinsk bakgrunn? Trolig ikke, siden den ikke «treffer» mine egne forskningsfelt. Derimot vil jeg som veileder helt sikkert av og til låne den bort og si «les regresjonskapitlet før vi diskuterer analysene dine videre». Har den en plass? Ja, jeg tror det. Det er ikke en bok man vil lese fra perm til perm, men den synes å kunne dekke et behov for korte, praktiske innføringer i avanserte (psykometriske) metoder, og hver enkelt leser kan plukke ett eller flere temaer som har relevans for egen forskning. Lærte jeg noe om et fagfelt jeg kun kjenner randsonen av? $\mathrm{Ja}$, definitivt. Men målgruppen er som sagt først og fremst psykologer med behov for mer inngående kunnskap om utvalgte metoder.

\section{Eva Skovlund}

Farmasøytisk institutt Universitetet i Oslo

\section{Hvordan møte minoritetsfamilier?}

Cecilie Jávo

\section{Kulturens betydning}

for oppdragelse og atferdsproblemer

Transkulturell forståelse, veiledning

og behandling. 259 s, ill. Oslo:

Universitetsforlaget, 2010. Pris NOK 299 ISBN 978-82-15-01616-0

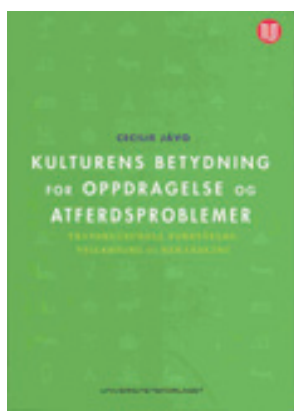

Forfatterens intensjon er å dekke et opplæringsbehov i kulturkompetanse for fagfolk som møter etniske minoritetsfamilier i sitt arbeid innen helse- og sosialsektoren. Læreboken tar utgangspunkt i forfatterens egen doktorgradsavhandling og senere forskning om barneoppdragelse og atferdsproblemer hos barn i samisk og norsk befolkning. Forfatteren går grundig til verks og gir nødvendig bakgrunnskunnskap om kultur og etnisitet. Hun forklarer bl.a. betydningen av etnisk identitet for god psykisk helse, hvordan akkulturasjonsstress kan føre til psykiske vansker, og hvordan kultursensitivitet kan bidra til å øke fagfolks bevissthet om egen og andres kulturer. Hun tar for seg barneoppdragelse i ulike kulturer, både i samisk kultur og i ikke-vestlige kulturer. Hun presiserer at egne normer ikke nødvendigvis er gyldige for andre. Hun definerer begrepet atferdsproblemer bredt og inkluderer både somatiseringsplager og emosjonelle vansker som angst og depresjon. Sammenhengen mellom kultur, barneoppdragelse og atferdsproblemer er uhyre kompleks, og hun gir gode eksempler på hvordan samme foreldreatferd kan få ulik virkning på barnet, avhengig av hvilken kulturell sammenheng den foregår i. En stor del er viet praktiske metoder og tilnærminger for hvordan man kan utføre kulturelt tilpassede utredninger og behandlinger av atferdsproblemer

Dagens tilbud til minoritetsfamilier her i Norge blir godt oppsummert, i tillegg til at ulike strategier $\mathrm{i}$ arbeidet med kulturtilpasning av tjenestetilbudet blir beskrevet. Internasjonalt er det godt dokumentert at minoritetsbefolkninger har dårligere tilgjengelighet til psykiske helsetjenester og at disse er for dårlig tilpasset språklig og kulturelt. Jávo beskriver at man kan gjøre tjenestene mer tilgjengelige ved å intensivere opplæringen i transkulturell behandling og kultursensitivt arbeid, øke tolketjenesten, ansette flere behandlere med minoritetsbakgrunn og utvikle samarbeidet med etniske minoritetsmiljøer. Til slutt gir hun gode eksempler på hvordan forebyggende og helsefremmede arbeid kan utføres, f.eks. etablering av Familiens Hus, som kan komme hele samfunnet til gode, inkludert den norske majoritetsbefolkningen.

Denne boken er blitt et lite prakteksemplar på hvordan skrive en forsknings- og erfaringsbasert bok. Store fagfelt som kultur, atferdsvansker og forebyggende arbeid blir nøye definert og godt forklart, både historiske perspektiver og nyere forskning blir innlemmet. Samtidig oppfordrer hun leseren til å forholde seg til de beskrivelsene som barnet og familien selv gir av sin egen virkelighet. Boken er krydret med kasuistikker og dialoger med samiske barn og barn av ikke-vestlige innvandrere og flyktninger. Ved å åpne for debatt om ulike, politiske stategier viser forfatteren et stort engasjement for sitt fagfelt.

Boken fyller absolutt et tomrom når det gjelder litteratur om hvordan man i praksis kan utføre kultursensitivt arbeid i Norge. For leger som jobber i barne- og ungdomspsykiatrien, bør denne boken være obligatorisk les- 